\title{
Critical Temperature Range in Standard and Ni-bearing Spheroidal Graphite Cast Irons
}

\author{
Roxana Maria GHERGU, ${ }^{1)}$ Jon SERTUCHA, ${ }^{2)}$ Yannick THEBAULT ${ }^{1)}$ and Jacques LACAZE ${ }^{1{ }^{*}}$ \\ 1) CIRIMAT, Université de Toulouse, BP 44362, 31030 Toulouse cedex 4, France. \\ 2) Ingeniería y Procesos de Fundición, IK4-AZTERLAN, Aliendalde auzunea 6, E-48200 Durango (Bizkaia), Spain.
}

(Received on May 15, 2012; accepted on July 17, 2012)

\begin{abstract}
Describing the conditions for reaustenitization of spheroidal graphite cast irons is of interest for their heat-treatment after casting, e.g. for manufacturing austempered ductile irons. Differential thermal analysis has been used to characterize the direct eutectoid transformation and the reverse transformation, i.e. the reaustenitization. This has been applied to a standard and a Ni-bearing alloy, with a ferritic matrix for the former, both a ferritic and a pearlitic matrix for the latter. The results are discussed in relation with the stable and metastable three phase fields. While earlier description of the direct eutectoid transformation is confirmed, the one for reverse eutectoid has been found more complex and is amended.
\end{abstract}

KEY WORDS: nodular cast irons; eutectoid transformation; austenitization; ferrite; pearlite.

\section{Introduction}

To control solid-state heat-treatment of cast irons, a precise knowledge of the effect of alloying elements on the stable (austenite-ferrite-graphite) and metastable (austenite-ferritecementite) three-phase fields is required. The corresponding temperature ranges have to be considered for describing the eutectoid transformation of austenite upon cooling as well as for controlling full or partial reaustenitization that may be called reverse eutectoid transformation. Recent interest has been focused on this latter for manufacturing austempered ductile irons (ADI) parts as stressed by a number of works dealing with kinetics of austenitization ${ }^{1,2)}$ and its physical modelling. ${ }^{3,4)}$ A clear understanding of the conditions for nucleation and growth of the new phases is necessary for modelling of direct and reverse eutectoid transformations.

In a previous work, the conditions for ferrite and pearlite growth upon cooling from the austenite field have been described on the basis of results obtained by differential thermal analysis (DTA) ${ }^{5,6)}$ Assuming their growth does not involve long range diffusion of substitutional solutes (e.g. $\mathrm{Si}, \mathrm{Cu}, \mathrm{Cr}, \mathrm{Mn}$, etc. $)^{7,8)}$ as must be the case for finite cooling rates, the characteristic temperatures for transformation could be evaluated on a $\mathrm{Fe}-\mathrm{C}$ isopleth section of the phase diagram drawn for the appropriate composition of the cast iron in substitutional solutes. Such a section for a $\mathrm{Fe}-\mathrm{C}-\mathrm{Si}$ alloy with 2.5 mass\% $\mathrm{Si}$ is shown in Fig. 1, ${ }^{7)}$ with the upper and lower temperatures of the three-phase field denoted $T_{\alpha}^{0}$ and $T_{\alpha}$ for the stable system, $T_{p}^{0}$ and $T_{p}$ for the metastable system. If ferrite precipitates as halos around graphite nodules and pearlite grows with no connection with graphite phase, it was thus found that growth of ferrite and pearlite

* Corresponding author: E-mail: jacques.lacaze@ensiacet.fr DOI: http://dx.doi.org/10.2355/isijinternational.52.2036 could proceed only when the lower temperature of the respective three-phase field has been reached. This approach has been applied successfully to explain that $\mathrm{Cu}$ and $\mathrm{Mn}$ favour pearlite because they both decrease the driving force for carbon diffusion in ferrite and decrease more $T_{\alpha}$ than $T_{p}{ }^{9,10)}$

Using the same hypothesis, this approach was extended to the reverse eutectoid transformation. ${ }^{11)}$ Upon heating, transformation of ferrite to austenite forming halos around the graphite phase should start at the upper limit of the stable three phase field $\left(T_{\alpha}^{0}\right)$ while decomposition of pearlite could proceed as soon as the lower limit of the metastable threephase field $\left(T_{p}\right)$ is reached as it is not related to the graphite phase. Predictions for both direct and reverse eutectoid transformations were confronted against an extensive review of literature data. ${ }^{7)}$ The agreement was good for finite scanning rates, though some features should be stressed:

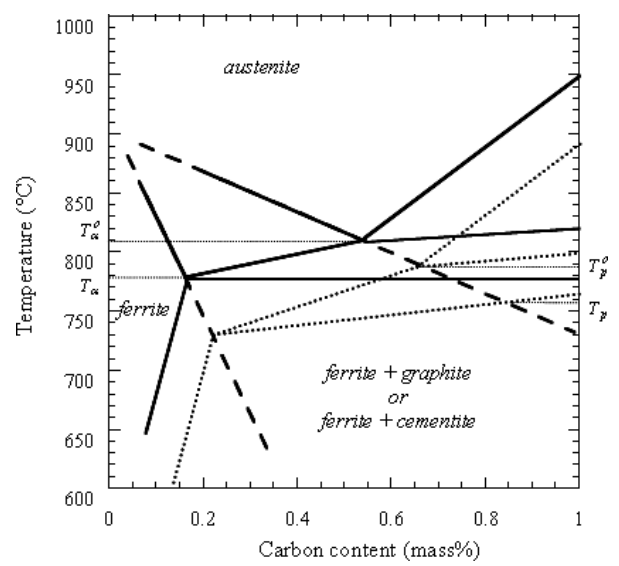

Fig. 1. Isopleth section of the stable (solid line) and metastable (dotted lines) $\mathrm{Fe}-\mathrm{C}-\mathrm{Si}$ phase diagrams. ${ }^{7)}$ 
- for very low scanning rates, in practice lower than $2 \mathrm{~K} /$ min, long range diffusion of substitutional solutes can take place in which case the stable transformation may start within the three-phase field. This would apply when partial reaustenitization is looked for as is the case for manufacturing so-called dual phase ADI. ${ }^{12,13)}$

- Upon cooling, the results showed that ferrite growth can start at very low undercooling with respect to $T_{\alpha}$ while pearlite needs some finite undercooling relative to $T_{p}$ to appear. ${ }^{14)}$ For modelling the eutectoid transformation, it has been accepted that ferrite appears at the interface between austenite and graphite ${ }^{15,16)}$ giving rise to the bull-eye structure. In some cases however, intergranular ferrite may precipitate upon cooling before bull-eye ferrite after reaustenitization. ${ }^{9)}$ Similarly, austenite has been observed to appear at the ferrite/ graphite interface for high heating rates ${ }^{17)}$ and at both the ferrite/graphite interface and grain boundaries upon reverse eutectoid transformation. ${ }^{17,18)}$

- For finite cooling rates, microsegregation issued from solidification was considered to affect only the last stage of the eutectoid transformation though the presence of even low levels of some alloying elements such as $\mathrm{Cr}, \mathrm{Mn}$ and $\mathrm{Cu}$ could favour pearlite instead of ferrite. ${ }^{19)}$ This effect has been related to chemical heterogeneities built-up during solidification and seems to more dramatically affect reaustenitization and subsequent solid-phase transformations ${ }^{18,20,21)}$ as compared to the direct eutectoid transformation during cooling after casting.

Since very few precise data were in fact available for checking the reaustenitization process against the former assumptions, ${ }^{7)}$ it seemed appropriate to test these latter. For this, an experimental investigation in which both ferritic and pearlitic matrix were processed has been performed. For such an attempt, it was decided to compare the transformation of a Ni-bearing cast iron that is prone to give a pearlitic matrix to a standard alloy. Both alloys were first studied after a ferritization treatment and the Ni-bearing one was also studied after a pearlitizing thermal cycle. DTA was used for controlling the heating and cooling of the samples.

\section{Experimental Details}

The alloys investigated have been prepared for previous studies and all details on melt preparation and casting conditions have already been given. ${ }^{22)}$ The content in the main alloying elements for the standard and the Ni-bearing grades are given in Table 1. The isopleth $\mathrm{Fe}-\mathrm{C}$ sections for the $\mathrm{Fe}-$ $\mathrm{C}-\mathrm{Si}$ and $\mathrm{Fe}-\mathrm{C}-\mathrm{Si}-\mathrm{Ni}$ alloys under investigation would be very similar to that shown in Fig. 1, with only slight changes in the characteristic temperatures. In this table are also listed the characteristic temperatures $\left({ }^{\circ} \mathrm{C}\right)$ estimated according to the following formulas where $\mathrm{w}_{\mathrm{i}}(\mathrm{mass} \%)$ is the alloying content of element " $i$ ": 7)

Table 1. Composition of the alloys (mass\%).

\begin{tabular}{lcccccccc}
\hline & $\mathrm{C}$ & $\mathrm{Si}$ & $\mathrm{Mn}$ & $\mathrm{Ni}$ & $T_{\alpha}^{0}$ & $T_{\alpha}$ & $T_{p}^{0}$ & $T_{p}$ \\
\hline standard grade & 3.73 & 2.08 & 0.13 & 0.01 & 805.2 & 782.6 & 781.3 & 770.9 \\
Ni-bearing grade & 3.89 & 1.88 & 0.13 & 0.92 & 773.5 & 750.4 & 765.2 & 734.4
\end{tabular}

$$
\begin{gathered}
T_{\alpha}^{o}=739+31.5 w_{S i}-7.7 w_{C u} \\
-18.7 w_{M n}+3.3 w_{M o}-10.7 w_{C r}-26.0 w_{N i} \ldots \ldots . \\
T_{\alpha}=739+18.4 w_{S i}+2.0\left(w_{S i}\right)^{2}-14.0 w_{C u} \\
-45.0 w_{M n}+2.0 w_{M o}-24.0 w_{C r}-27.5 w_{N i} \cdots . . \\
T_{p}^{o}=727+30.07 w_{S i}-1.98\left(w_{S i}\right)^{2} \\
-10.7 w_{C u}-13.7 w_{M n}+9.3 w_{M o}+24.3 w_{C r}-12.0 w_{N i} \\
T_{p}=727+21.6 w_{S i}+0.023\left(w_{S i}\right)^{2} \\
-21.0 w_{C u}-25.0 w_{M n}+8.0 w_{M o}+13.0 w_{C r}-33.0 w_{N i}
\end{gathered}
$$

These formulas have been calculated using a thermodynamic software and associated databases as previously described. ${ }^{7}$ They are thus valid for the low carbon content that prevails at the eutectoid reaction, and account should be made of the presence of graphite that leads to redistribution of all alloying elements but carbon in the matrix. Accordingly, the $\mathrm{w}_{\mathrm{i}}$ values entered in the formulas for evaluating the characteristic temperatures of an alloy are 1.05 times those listed in Table 1.7)

DTA experiments were performed with a SETARAM SETSYS apparatus, with alumina powder as reference material and samples machined out from the cast irons with a diameter of $3.9 \mathrm{~mm}$ and a height of $5 \mathrm{~mm}$. The DTA cell is regularly checked against transformation temperature of pure elements, namely melting of aluminium, silver, iron and nickel. The accuracy on the temperatures reported here is estimated to be $\pm 2{ }^{\circ} \mathrm{C}$.

As received, the standard alloy showed an as-cast ferritopearlitic matrix and it was guessed that pearlite should start to decompose to ferrite and graphite upon heating at a temperature far below the metastable three-phase field. It was thus considered more significant to study only the transformation of ferrite upon heating of this alloy. DTA samples were thus subjected to a subcritical anneal which consisted in heating at a rate of $10 \mathrm{~K} / \mathrm{min}$ to $720^{\circ} \mathrm{C}$, holding for $60 \mathrm{~min}$ and then cooling to $400^{\circ} \mathrm{C}$ at $2 \mathrm{~K} / \mathrm{min}$. The first sample was then cooled to room temperature (RT) and it was checked that all pearlite had decomposed. The subsequent samples were maintained for $1 \mathrm{~min}$ at $400^{\circ} \mathrm{C}$ after the subcritical anneal and then heated to $950^{\circ} \mathrm{C}$, held 5 minutes and then cooled to RT. The heating and cooling rates used were 2,5 , 10,15 and $20 \mathrm{~K} / \mathrm{min}$.

In the as-received condition, the Ni-bearing material had been ferritized by means of a subcritical anneal. ${ }^{22)}$ A first set of DTA experiments was thus conducted to investigate the effect of heating rate on the transformation of ferrite to austenite with upper temperature set at $1050^{\circ} \mathrm{C}$. Upon cooling, the effect of the scanning rate on the transformation of austenite to a ferrito-pearlitic matrix was investigated. Finally, for studying the effect of the heating rate on the transformation of pearlite to austenite, the samples were first heated to $1050^{\circ} \mathrm{C}$, then cooled at the highest possible rate (about $60 \mathrm{~K} / \mathrm{min}$ in the eutectoid range) to maximize the amount of pearlite, and finally reheated to $1050^{\circ} \mathrm{C}$ and cooled to RT for the same range of scanning rates as above. Figure $\mathbf{2}$ shows the nearly fully pearlitic matrix obtained after rapid cooling from $1050{ }^{\circ} \mathrm{C}$. 


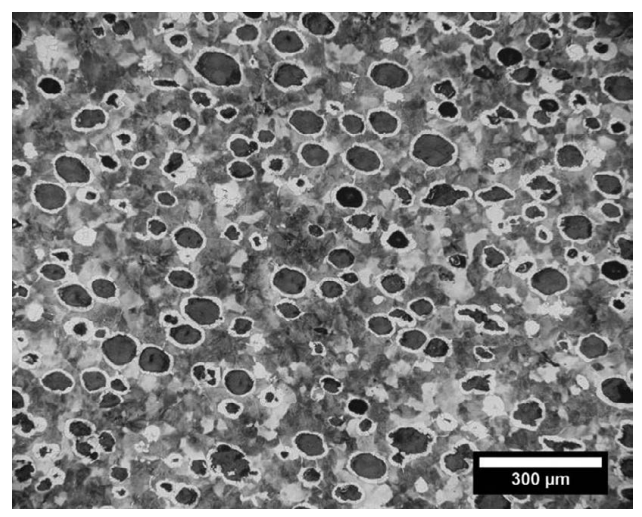

Fig. 2. Micrograph of the Ni-bearing alloy with nearly fully pearlitic matrix obtained after rapid cooling from $1050^{\circ} \mathrm{C}$.

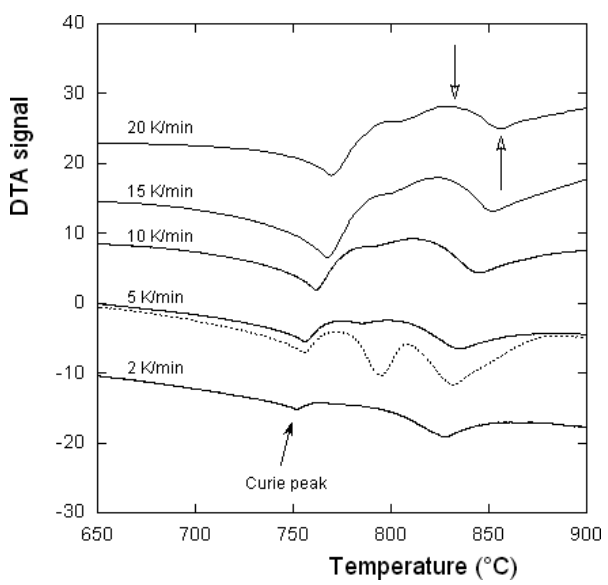

Fig. 3. DTA records upon heating the standard material in the ferritized state (solid lines) and in the as-received condition (dotted line).

\section{Results}

Figure 3 shows the five DTA records obtained upon heating the ferritized standard alloy up to $950^{\circ} \mathrm{C}$ at different rates (solid lines) plus the record corresponding to the asreceived alloy with a $5 \mathrm{~K} / \mathrm{min}$ heating rate (dotted line). Note that, in this figure and the following, the records have been shifted along the ordinate direction for clarity. Comparing the two records at the heating rate of $5 \mathrm{~K} / \mathrm{min}$, it is seen that the as-received material shows three peaks while the ferritized one shows only two peaks. It is thus easy to associate the peak at intermediate temperature with pearlite decomposition, while the peak at lower temperature relates to the magnetic transformation of ferrite and that at higher temperature to the transformation of ferrite to austenite. It could be noticed however that a small bump is still apparent at intermediate temperatures on all DTA records with the ferritized samples, indicating that a small amount of pearlite was anyway present.

The temperature for the beginning of austenite formation and the peak temperature of the thermal arrest related to ferrite decomposition were recorded as indicated by the open arrows in Fig. 3. While the latter is easily evaluated, the former is subject to a higher uncertainty. The obtained values for ferrite transformation start and ferrite peak are listed in Table 2.

The DTA records obtained on cooling the samples of the standard alloy are shown in Fig. 4. On each of these records,
Table 2. Characteristic transformation temperatures $\left({ }^{\circ} \mathrm{C}\right)$ evaluated on the DTA records of the ferritized standard cast iron for various scanning rates $\left({ }^{\circ} \mathrm{C} / \mathrm{min}\right)$.

\begin{tabular}{c|cc|ccc}
\hline & \multicolumn{2}{|c|}{ Heating } & \multicolumn{3}{c}{ Cooling } \\
\hline $\begin{array}{c}\text { Scanning } \\
\text { rate }\end{array}$ & $\begin{array}{c}\text { Ferrite } \\
\text { start }\end{array}$ & $\begin{array}{c}\text { Ferrite } \\
\text { peak }\end{array}$ & $\begin{array}{c}\text { Ferrite } \\
\text { start }\end{array}$ & $\begin{array}{c}\text { Pearlite } \\
\text { start }\end{array}$ & $\begin{array}{c}\text { Pearlite } \\
\text { peak }\end{array}$ \\
\hline 2 & 785 & 828 & 778 & 736 & 724 \\
5 & 804 & 835 & 764 & 730 & 712 \\
10 & 816 & 845 & 757 & 717 & 698 \\
15 & 826 & 853 & 746 & 708 & 686 \\
20 & 833 & 856 & 741 & 701 & 678 \\
\hline
\end{tabular}

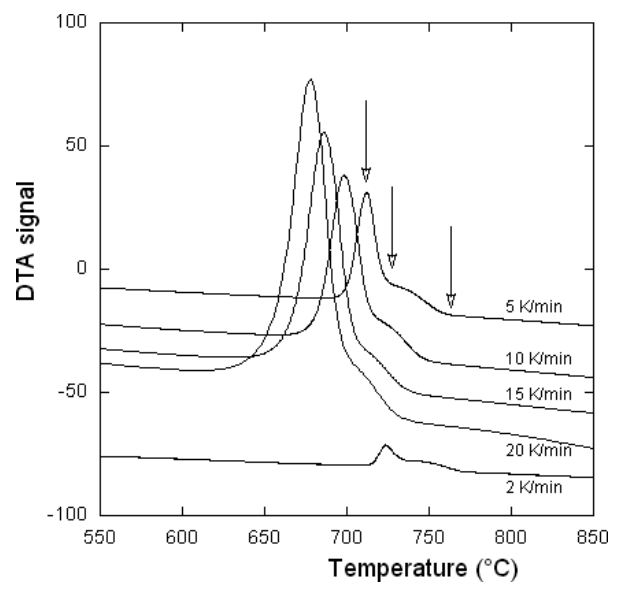

Fig. 4. DTA records upon cooling the standard material from $950^{\circ} \mathrm{C}$.

two thermal arrests are clearly distinguished that relate to the appearance of ferrite for the high temperature and the formation of pearlite for the low temperature. As expected, the relative amplitude of the former with respect to the latter decreases as the cooling rate is increased. As indicated with the open arrows in Fig. 4, the characteristic temperatures that could be evaluated, namely the start of ferrite precipitation, the start of pearlite precipitation and the peak temperature associated to pearlite, are listed in Table 2. As mentioned before, the start of the transformations is evaluated with a higher uncertainty than the peak temperature.

The set of characteristic temperatures have been plotted in Fig. 5 as function of the square root of the scanning rate during the DTA run. Looking first at the transformation temperature from austenite to ferrite upon cooling, it is seen that the data extrapolates to $T_{\alpha}$ with the value for the lowest cooling rate slightly above the regression line as expected. The two series of data for pearlite formation upon cooling, namely the start and peak temperatures, may be extrapolated to nearly the same temperature i.e. $20^{\circ} \mathrm{C}$ below $T_{p}$. That pearlite needs such an underccoling to appear is in agreement with previous works. ${ }^{6,9,14)}$ Summing up, the results obtained upon cooling the standard alloy agree with those expected according to the proposed model for the eutectoid transformation. ${ }^{11)}$

On the contrary, the data for ferrite transformation to austenite upon heating are at definite difference with respect to those expected. The temperature associated with the start of ferrite decomposition may be extrapolated to a temperature close to $T_{\alpha}$ at zero scanning rate. This means that the transformation proceeds within the three phase field and thus that austenite does not form halos around the graphite nodules as 


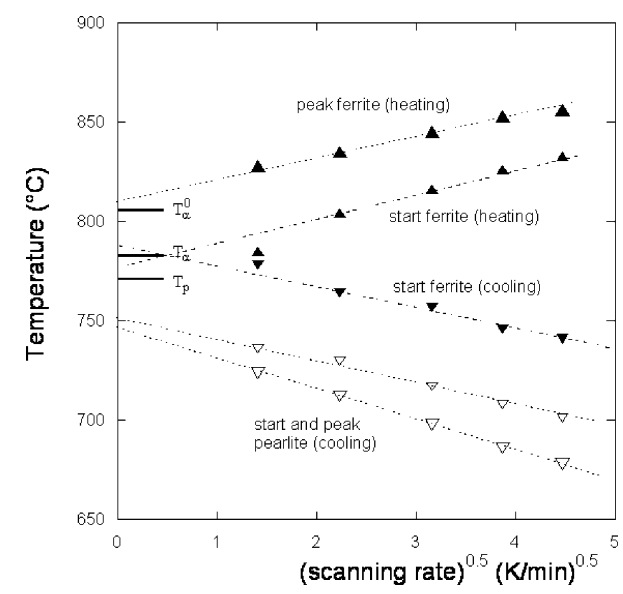

Fig. 5. Evolution of the characteristic temperatures of the DTA records obtained for the standard material as function of the square root of the scanning rate. Solid symbols are for the ferritic reaction, open symbols for the pearlitic one.

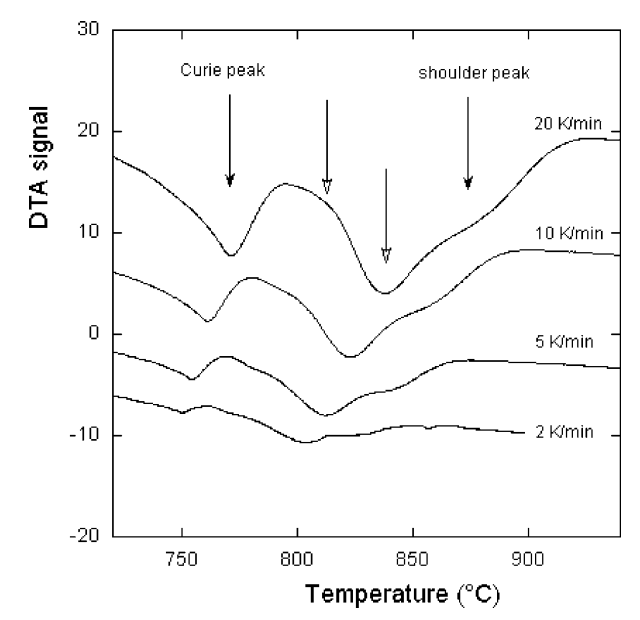

Fig. 6. DTA records upon heating the Ni-bearing material in the ferritized state.

postulated in earlier work. ${ }^{11)}$ Instead, the transformation must proceed by the growth of austenite along grain boundaries as reported by several authors ${ }^{17,18,23)}$ and is controlled by carbon diffusion along these grain boundaries.

Figure 6 presents the DTA records on heating to $1050^{\circ} \mathrm{C}$ of the as-received ferritized Ni-bearing material. These records show two main peaks, the Curie peak at low temperature and the peak associated with the ferrite to austenite transformation at higher temperatures. On all records, a shoulder peak at even higher temperature could be observed indicating that the transformation of ferrite to austenite is much longer for this alloy than for the standard one. The temperature for the start of ferrite decomposition and the peak temperature (open arrows in Fig. 6) have been considered as characteristic temperatures and are listed in Table 3.

Figure 7 shows the DTA records upon heating after the Ni-bearing material had been heated up to $1050^{\circ} \mathrm{C}$ and rapidly cooled to RT to get a nearly fully pearlitic matrix. The records all show three peaks, as for the dotted curve in Fig. 3 , which can be allocated to the Curie transformation, pearlite decomposition and ferrite transformation at increasing temperature. It is seen that the height of the peak associated with ferrite increases with respect to that of pearlite as the scanning rate is decreased. This shows that, though stabi-
Table 3. Characteristic transformation temperatures $\left({ }^{\circ} \mathrm{C}\right)$ evaluated on the DTA records of the Ni-bearing cast iron for various scanning rates $\left({ }^{\circ} \mathrm{C} / \mathrm{min}\right)$.

\begin{tabular}{|c|c|c|c|c|c|c|c|c|}
\hline \multirow[b]{2}{*}{$\begin{array}{c}\text { Scanning } \\
\text { rate }\end{array}$} & \multicolumn{2}{|c|}{$\begin{array}{c}\text { Heating } \\
\text { Ferritized material }\end{array}$} & \multicolumn{3}{|c|}{$\begin{array}{c}\text { Heating } \\
\text { Pearlitized material }\end{array}$} & \multicolumn{3}{|c|}{$\begin{array}{c}\text { Cooling } \\
\text { Pearlitized material }\end{array}$} \\
\hline & $\begin{array}{c}\text { Ferrite } \\
\text { start }\end{array}$ & $\begin{array}{c}\text { Ferrite } \\
\text { peak }\end{array}$ & $\begin{array}{c}\text { Pearlite } \\
\text { start }\end{array}$ & $\begin{array}{c}\text { Pearlite } \\
\text { peak }\end{array}$ & $\begin{array}{l}\text { ferrite } \\
\text { peak }\end{array}$ & $\begin{array}{c}\text { Ferrite } \\
\text { start }\end{array}$ & $\begin{array}{l}\text { Pearlite } \\
\text { start }\end{array}$ & $\begin{array}{l}\text { Pearlite } \\
\text { peak }\end{array}$ \\
\hline 2 & 785 & 804 & 763 & 769 & 802 & 742 & 707 & 703 \\
\hline 5 & 791 & 812 & 767 & 778 & 809 & 734 & 699 & 690 \\
\hline 10 & 801 & 823 & 776 & 789 & 818 & 727 & 687 & 675 \\
\hline 15 & & & 781 & 799 & 822 & 721 & 680 & 663 \\
\hline 20 & 814 & 838 & 788 & 806 & 830 & 714 & 672 & 653 \\
\hline
\end{tabular}

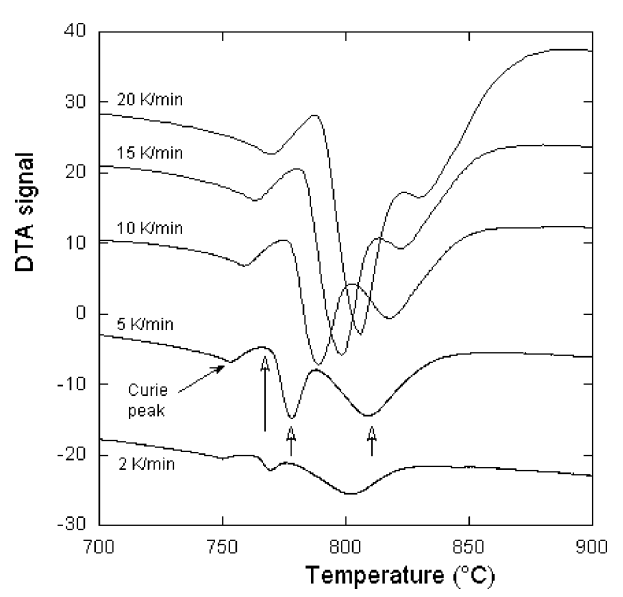

Fig. 7. DTA records upon heating the Ni-bearing material in the pearlitized state.

lized by nickel, some of the pearlite transforms to ferrite and graphite during heating before it decomposes to austenite when the temperature is high enough. The characteristic temperatures considered here are the start and peak temperatures for pearlite transformation and the peak temperature for ferrite transformation to austenite as it is shown with the open arrows in Fig. 7. Note that there are no shoulders on the high temperature side of the ferrite peak appearing, this will be discussed further below.

Finally, Fig. 8 shows the set of DTA records that were obtained from the Ni-bearing alloy upon cooling during the second series of experiments. As the initial conditions before cooling were the same in the first series of experiments, i.e. a short holding after heating to $1050^{\circ} \mathrm{C}$, the records obtained upon cooling during the first and second series were similar. The characteristic temperatures considered in Fig. 8 are the same as for Fig. 4, i.e. the start of ferrite precipitation, the start of pearlite precipitation and the peak temperature associated to pearlite, they are listed in Table 3.

The characteristic temperatures obtained from Figs. 6, 7 and 8 have been plotted in Fig. 9. Starting again with the transformation upon cooling, it is seen that the start of ferrite growth corresponds well to $T_{\alpha}$. Similarly, the two characteristic temperatures for formation of pearlite upon cooling may be extrapolated to a single temperature that is about $10^{\circ} \mathrm{C}$ below $T_{p}$. These results agree with predictions ${ }^{11)}$ as was already the case for the standard alloy.

Concerning the transformation from ferrite to austenite upon heating, it is seen that the temperature for the start of 


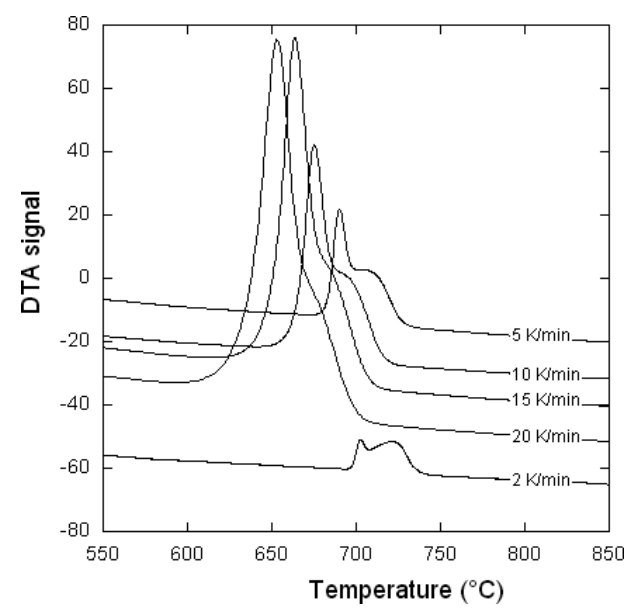

Fig. 8. DTA records upon cooling the Ni-bearing material from $1050^{\circ} \mathrm{C}$

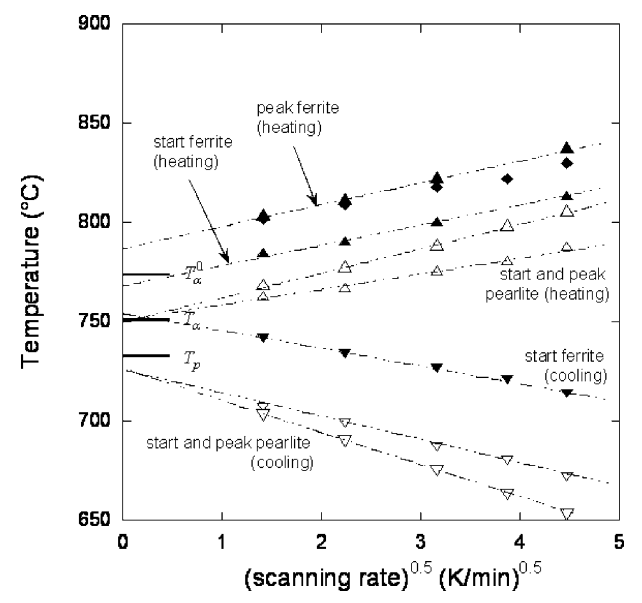

Fig. 9. Evolution of the characteristic temperatures of the DTA records obtained for the Ni-bearing material as function of the square root of the scanning rate. Solid symbols are for the ferritic reactions, open symbols for the pearlitic one. Solid diamonds are for the material with initially a pearlitic matrix.

this reaction in an initially fully ferritic matrix may well be extrapolated to $T_{\alpha}^{0}$ as expected from the model. This should mean that for this alloy the transformation proceeds, at least for a part, by the formation and growth of austenite halos around graphite nodules, and this is contrary to the result on the standard alloy presented above. This is further discussed in the next section.

Decomposition of pearlite during heating shows start and peak characteristic temperatures that may well be extrapolated to the same temperature that appears to be significantly higher than $T_{p}$ and in fact quite close to $T_{\alpha}$. This suggests that decomposition of pearlite to austenite upon heating proceeds provided the material temperature is above $T_{\alpha}$, i.e. with the condition that austenite may be stable at that temperature. Thus, the description that have been proposed previously ${ }^{11)}$ must be modified: decomposition of pearlite to austenite will start at $T_{p}$ if this temperature is higher than $T_{\alpha}$, it will start at $T_{\alpha}$ in the opposite case as for this Ni-bearing alloy.

\section{Discussion}

In Fig. 9 it is noticed that the peak temperature for ferrite transformation is about the same whatever the initial matrix,
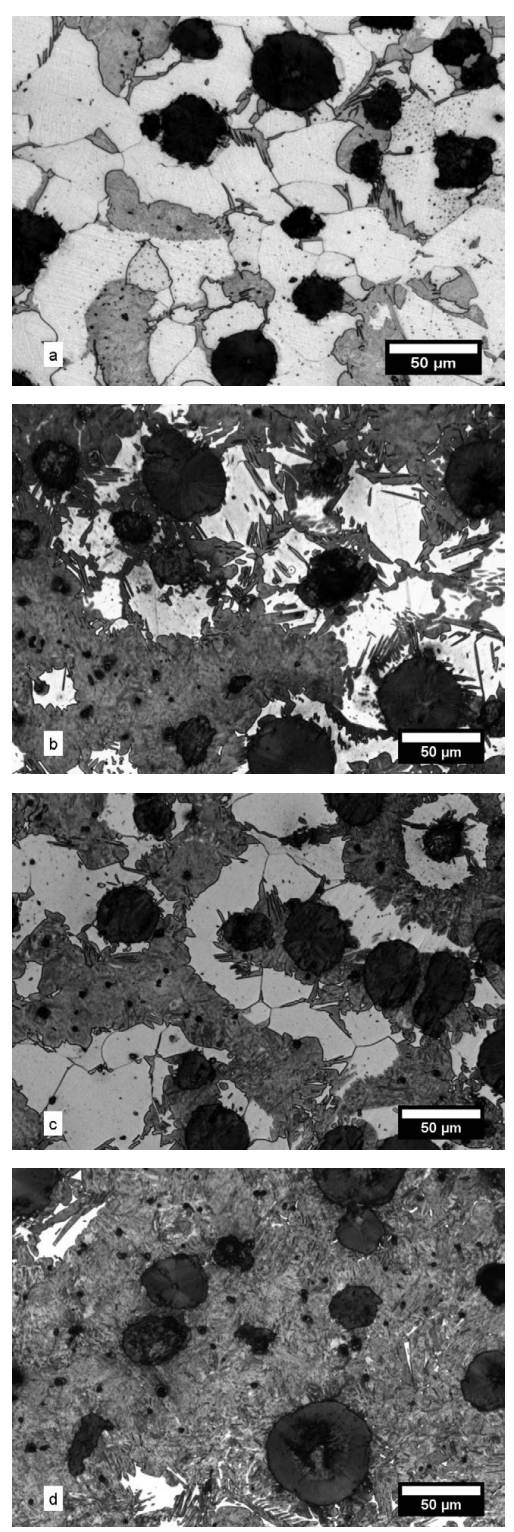

Fig. 10. Optical micrograph after etching with $2 \%$ Nital of $\mathrm{Ni}$ bearing samples held 5 minutes (a dnd c) and 15 minutes (b and d) at $800^{\circ} \mathrm{C}$ (a and b) and 5 and 15 minutes at $825^{\circ} \mathrm{C}$ (c and d).

ferritic or pearlitic. This suggests that this peak relates to the same part of the material at the microstructure scale, and hence that the ferrite associated to the shoulder detected in alloys with an initially ferritic matrix (see Fig. 6) gives rise to the pearlite that first transforms after pearlitization. For a more precise understanding of the origin of the shoulders, samples of the ferritized Ni-bearing alloy have been heattreated by introducing them in a furnace at either $800^{\circ} \mathrm{C}$ or $825^{\circ} \mathrm{C}$ for 5 and 15 minutes, and then quenched into brine. Typical micrographs of each sample are shown in Fig. 10 where it is seen that austenite (appearing as martensite after quenching) forms at the graphite/ferrite interface but also at cell boundaries away from the graphite nodules (Figs. 10(a) and $10(\mathrm{~b}))$. Growth of austenite then proceeds by thickening of the austenite shell around the graphite nodules and of the austenite formed at cell boundaries (Fig. 10(c)) and finishes in the regions in between nodules and cell boundaries (Fig. 10(d)) which are then associated to the shoulders.

Using a sample of the Ni-bearing alloy that had been 


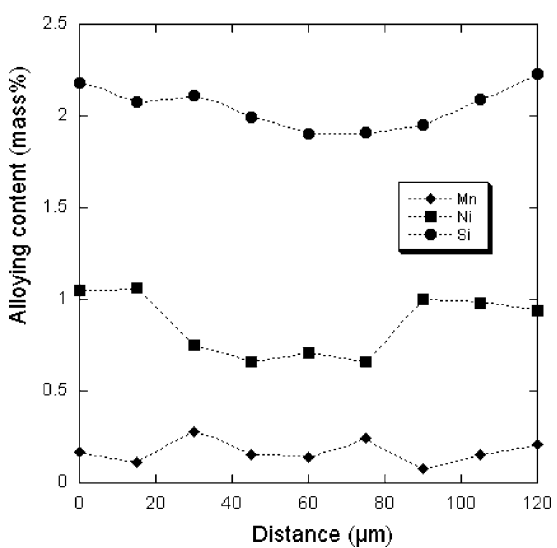

Fig. 11. Example of composition profile in between two nodules in the Ni-bearing alloy.

Table 4. Estimates of the $T_{\alpha}$ temperature at locations close to the graphite nodules and at cell boundaries.

\begin{tabular}{lcc}
\hline & Standard alloy & Ni-bearing alloy \\
\hline Nodule/ferrite interface & 774.9 & 754.0 \\
Intercellular areas & 769.8 & 758.8 \\
\hline
\end{tabular}

pearlitized, a few line-scans between two neighbouring graphite nodules were recorded using an energy dispersive $\mathrm{X}$-ray spectrometry (EDS) system on a scanning electron microscope (SEM). One of these line-scans is shown in Fig. 11 where it is seen that $\mathrm{Si}$ and $\mathrm{Ni}$ contents decrease as expected from the graphite/matrix interface to the internodule areas, from 2.2 mass $\%$ to 1.9 mass $\%$ for $\mathrm{Si}$ and from 1.05 mass \% to 0.6 mass\% for Ni. Because of the low $\mathrm{Mn}$ content, this element appears more erratic when an increase would have been expected, thus it will be considered as constant at 0.14 mass $\%$ in the following. The Si profile in the standard alloy could be similarly considered to change from 2.0 mass $\%$ to 1.7 mass\% while the $\mathrm{Mn}$ was again taken as constant at 0.14 mass $\%$.

Using the compositions mentioned above, the $T_{\alpha}$ temperature could be estimated by means of Eq. (2) for locations close to the graphite nodules and at cell boundaries. The values obtained are listed in Table 4. It appears clearly that the difference in the reaustenitizing process between the two alloys may be directly related to the change in $T_{\alpha}$ value from the graphite/ferrite interface to cell boundaries: this change is negative for the standard alloy while it is positive for the Ni-bearing alloy. Thus, for the standard alloy, transformation of ferrite to austenite could start at lower temperature in the cell boundaries provided carbon can diffuse from the graphite nodules to these areas. As mentioned above, several authors have observed this for the intermediate heating rates investigated in the present work. In the case of the Nibearing alloy, the decomposition of ferrite to austenite is not favoured at cell boundaries (see Table 4) and the transformation should preferentially start with the formation of austenite halos around nodules when the material temperature has reached $T_{\alpha}^{0}$. The microstructures in Fig. 10 show that both transformation processes do in fact compete for this alloy. This discussion shows the importance of microsegregation in the reaustenitization process.

\section{Conclusion}

The DTA results obtained in the present study upon cooling from the austenite + graphite field are in full agreement with previous reports and confirm the model proposed for the eutectoid transformation. On the other hand, the DTA results upon heating the materials and the few micrograph observations performed show that the previously developed model for reverse eutectoid transformation had to be challenged with new experiments. The following conclusions could be drawn for reaustenitization of a ferritic matrix:

- in standard cast irons with very low levels of alloying additions, segregation of $\mathrm{Si}$ is such that the predicted ferrite to austenite transformation temperature is lower at cell boundaries than at the nodule/ferrite interfaces. Thus, austenite appears at cell boundaries and grows by carbon diffusion along grain boundaries at a temperature lower than the $T_{\alpha}^{0}$ temperature of the alloy. The reference temperature for ferrite decomposition is then $T_{\alpha}$.

- Negative segregation of Ni leads to a predicted transformation temperature for ferrite lower at the graphite/ ferrite interface than at cell boundaries, so that austenite halos may form around the nodules before ferrite starts transforming at cell boundaries. In that case, the reference temperature for ferrite decomposition is $T_{\alpha}^{0}$.

In the case of a pearlitic matrix, decomposition of pearlite to austenite needs this latter to be stable which is possible if the $T_{\alpha}$ temperature of the alloy is lower than its $T_{p}$ temperature. In such a case, the reference temperature for the start of pearlite decomposition is $T_{p}$ while it will be $T_{\alpha}$ in the opposite case. The previous model for pearlite decomposition upon heating may be made more precise by stating that the temperature at which it starts is the highest of $T_{\alpha}$ and $T_{p}$.

\section{REFERENCES}

1) R. C. Thomson, J. S. James and D. C. Putman: MST, 16 (2000), 1412.

2) R. Ivanova, W. Sha and S. Malinov: ISIJ Int., 44 (2004), 886.

3) W. Kapturkiewicz, E. Fras and A. A. Burbelko: $M S E$ A, 413-414 (2005), 352.

4) Uma Batra, S. Ray and S. R. Prabhakar: JMEPEG, 14 (2005), 574

5) J. Lacaze, S. Ford, C. Wilson and E. Dubu: Scand. J. Metall., 22 (1993), 300.

6) J. Lacaze, C. Wilson and C. Bak: Scand. J. Metall., 23 (1994), 151.

7) V. Gerval and J. Lacaze: ISIJ Int., 40 (2000), 386.

8) S. N. Lekakh and V. L. Richards: AFS Trans., 118 (2010), 225.

9) J. Lacaze, A. Boudot, V. Gerval, D. Oquab and H. Santos: Metall. Mater. Trans. A, 28A (1997), 2015.

10) J. Sertucha, P. Larrañaga, J. Lacaze and M. Insausti: Int. J. Metalcasting, 4 (2010), 51.

11) E. Linares, V. Gerval and J. Lacaze: Scr. Mater, 38 (1998), 279.

12) A. Basso, R. Martinez and J. Sikora: Key Eng. Mater., 457 (2011), 145.

13) A. P. Druschitz, R. E. Aristizabal, E. Druschitz, C. R. Hubbard, T. R. Watkins, L. Walker and M. Ostrander: Metall. Mater. Trans. A, 43A (2012), 1468.

14) J. Lacaze: Int. J. Cast Metals Res., 11 (1999), 431.

15) M. Wessén and I. Svensson: Metall. Mater. Trans. A, 27A (1996), 2209.

16) J. Lacaze and V. Gerval: ISIJ Int., 38 (1998), 714.

17) N. Wade and Y. Ueda: Trans. Iron Steel Inst. Jpn., 20 (1980), 857.

18) J. M. Chou, M. H. Hon and J. L. Lee: Scr. Metall. Mater., 27 (1992), 61 .

19) J. Lacaze: Proc. of Erstarrung Metallischer Schmelzen in Forschung and Giessereipraxis, ed. by A. Ludwig, Wiley-VCH, Weinheim, (1999), 25.

20) J. Sikora and R. Boeri: Int. J. Cast Metals Res., 11 (1999), 395.

21) J. M. Schissler and J. Saverna: J. Heat Treating, 4 (1985), 167.

22) J. Lacaze, P. Larrañaga, I. Asenjo, R. Suárez and J. Sertucha: MST, 28 (2012), 603.

23) J. E. Rehder: AFS Trans., 73 (1965), 473. 